\title{
Article
}

\section{Halal Integrity in the Food Supply Chain}

Soon, Jan Mei, Chandia, Mahmood and Regenstein, Joe Mac

Available at http://clok.uclan.ac.uk/15438/

Soon, Jan Mei ORCID: 0000-0003-0488-1434, Chandia, Mahmood ORCID: 0000-0002-3900-2674 and Regenstein, Joe Mac (2017) Halal Integrity in the Food Supply Chain. British Food Journal, 119 (1). pp. 39-51. ISSN 0007-070X

It is advisable to refer to the publisher's version if you intend to cite from the work. http://dx.doi.org/10.1108/BFJ-04-2016-0150

For more information about UCLan's research in this area go to http://www.uclan.ac.uk/researchgroups/ and search for < name of research Group>.

For information about Research generally at UCLan please go to http://www.uclan.ac.uk/research/

All outputs in CLoK are protected by Intellectual Property Rights law, including Copyright law. Copyright, IPR and Moral Rights for the works on this site are retained by the individual authors and/or other copyright owners. Terms and conditions for use of this material are defined in the policies page.

\section{CLoK}

Central Lancashire online Knowledge www.clok.uclan.ac.uk

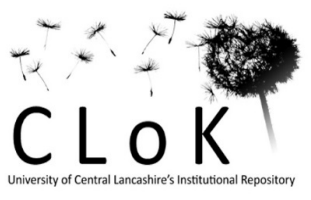


British Food Journal

Emerald

British Food Journal

Halal Integrity in the Food Supply Chain

\begin{tabular}{|r|l|}
\hline Journal: & British Food Journal \\
\hline Manuscript ID & BFJ-04-2016-0150.R2 \\
\hline Manuscript Type: & General Review \\
\hline Keywords: & halal, halal certification, haram, Islam, Muslims, traceability \\
\hline \multicolumn{2}{|l}{} \\
\hline
\end{tabular}

$$
\text { SCHOLARONE }{ }^{m}
$$

Manuscripts 


\section{Halal Integrity in the Food Supply Chain}

3 Abstract

4 Purpose: This paper argues that there is an absence of halal integrity within the conventional stages

5 of a food chain. This paper adapts the understanding of the different stages and argues the need to

6 develop a critical consciousness for halal integrity within the food chain to address the needs of the

7 ever-growing Muslim consumers' market. The aim of this paper is to propose a definition of halal

Design: The study includes a review of priori literature and media reports regarding cross contamination of food products with haram (forbidden) components. This background will be used to

Findings: Different interpretations of halal - what is permitted and what is prohibited - exist for the

different schools of Islamic legal thought and within the customs of different countries. In order to ensure that food production is embracive of the religious needs of the global Muslim customer market, this paper utilises the farm to fork and global supply chain models to foster a critical awareness of halal needs. Halal integrity should be clearly presenting the details of the halal status of the product and assuring that the requirements for halal as stated are met. Halal integrity not only deals with permitted and prohibited foods, but that the halal status of the food products (i.e. from raw materials until it reaches the consumers) should not be breached (i.e. no cross contamination with haram products / methods and no ill intents). A formal definition of halal integrity has been proposed.

Research limitations: The SWOT analyses serve as a guideline as the analysis done may be outdated as the environments are constantly changing.

Originality/value - This research although academic is meant to have a real value in improving the integrity of the halal food supply chain, providing value to the food industry, to countries that are concerned about this supply chain and to Muslim consumers. Halal integrity is crucial to the success of the emerging halal market.

Keywords: food supply chain; halal; halal certification; haram; Islam; Muslims; traceability

37 2004). These principles extend beyond dietary requirements and underpin all types of human conduct 38 for adherents of the Islamic faith, including beliefs, actions, diet, clothes, modes of earnings, 
relationships, etc. The term 'halal' with reference to food covers all the aspects starting from the farm and ending at the table of a halal observant home. Halal food must be free of any components that Muslims are prohibited from consuming, which is known as haram. Based on Qur'ānic guidance (Qur'an, 2:168, cited in Chandia, 2015), all foods are halal except those that are specifically mentioned as haram. Haram foods can be divided into several main categories, and include any products derived from or contaminated with these prohibited materials, e.g.such as, carrion, blood, pig, permitted animals slaughtered incorrectly, and intoxicants. Recently, examples of haram contamination and dishonest behaviour with halal certified products highlight (Table 1) areas of concern to Muslim consumers as they are dependent on the food industry and policy makers to assure the integrity of the halal supply chain. Food processors may choose to use pork derivatives, other non-halal slaughtered meats and gelatine to substitute meat products because they are cheap and readily available (Aida et al., 2005). This raises the question of what is halal integrity and what measures can be taken to assure that products are produced and handled with integrity? The paper aims to provide an eclectic appreciation of relevant sources, critically understand their nuances and implications to bridge the needs of halal integrity within the food chain. This is supported by providing a critical independent analysis which presents an ethical framework that is more embracive of the religious needs of more than 1.5 billion (and ever-increasing) people of the world and (arguably) is very pragmatic for both operational and strategic implementation and monitoringboth local producers and exporters alike. This paper will define halal integrity and-attempt to conceptualise the context of halal using the farm to fork and global supply chain models to define halal integrity-develop operational and strategic conceptual frameworks. The frameworks models will assist food manufacturers, food traders and policy makers to ensure the halal integrity of the local and global food supply chains.

\section{Insert Table 1 here}

\section{Methodology}

A desktop review of priori literature on primary religious and academic sources were conducted.and mMedia reports of cross contamination of halal food products and fraud-related cases were collated to present the data (in-Table 1). The literature research was conducted by using various databases like EBSCO, Science Direct, Taylor and Francis Online and news. Keywords such as pork or porcine detection, halal food, haram and mislabelling were used in the databases. in order to acquire a eoherent narrative on emerging themes and trends. This is followed by a critical independent analysis to conceptualise integrity in the context of halal present two conceptual frameworks that are embracive of the religious needs of Muslim customer market.using a farm to fork model and a global supply chain model. SWOT analyses were carried out to demonstrate the internal (i.e. strengths and weaknesses) and external environments (i.e. opportunities and threats) faced during international halal food trade. - - the models are then used to define halal integrity. 


\section{Halal food supply chain (operational Hevel)}

A halal food supply chain starts with sourcing various permitted raw materials and preparing them accordingly (e.g.such as, proper halal slaughter and no cross-contamination with haram products). During all stages of halal production, it is crucial that the food is sourced lawfully, i.e., free from corruption, dishonesty and with no malicious intention (Figure 1). For example, only permitted species are farmed and these halal species do not consume haram feed provided by humans. However, if eaten naturally, then this is not an issue. The schematic diagram below highlights the different stages where halal integrity needs to be considered and preserved (Figure 1).

Insert Figure 1 here

101

Many of the major stages found in the food supply chain (Soon and Baines, 2013; Soon et al., 2012)

104

Agricultural Phase: The inputs (e.g-such as seedlings, plantlets, fertilisers, pesticides, irrigation water, feed, and veterinary products) used during this phase need to be sourced and used according to legal requirements. Irrigation water for produce and crops, drinking water in animal husbandry production, and water sources from where aquaculture products are grown/marine products (including freshwater fish) are caught should be safe and not within the vicinity of pig farms or run-off from pig farms.

Slaughtering Phase: It is permitted to slaughter animals without stunning to meet Jewish and Muslim 113 halal and non-halal meat occurs at this point (Bergeaud-Blackler 2007). According to Lever and Miele 114 (2012), the practice of religious slaughter in this case addresses the qualification of halal and is 
115 comparable to other credence attributes that refer to the method of production rather than the

116 intrinsic characteristics of the product. Hence all operations that occur downstream should guarantee

117 the separation and integrity of halal products (Bergeaud-Blackler 2007). For halal it is required to use

118 the Islamic method provided that the animals are slaughtered by a Muslim slaughterman. The Muslim

119 slaughter person must be an adult male or female of sound mind familiar with the process of

120 slaughtering. A trained slaughter person will be more efficient and will minimize the damage to the

121 skin and carcass (Riaz and Chaudry, 2004). It is an absolute requirement that animals are

122 slaughtered according to the halal method. The Muslim slaughter person must sever the front part of

123 the neck, severing carotids, jugulars, trachea and esophagus without reaching the bone in the neck

124 while pronouncing the name of God and with a swift blow (Riaz and Chaudry, 2004). It is preferable

125 to turn the animal or bird towards Makkah (Mecca) before slaughtering although this is only a

126 secondary requirement. The slaughtering of ruminants and poultry should preferably be done by

127 hand. It is mandatory to pronounce the name of God while slaughtering the animal. It suffices to say

128 Bismillah (in the name of God) once (Riaz and Chaudry, 2004). However, in general practice,

129 especially for large animals, the slaughter person pronounces the name thrice as Bismillah Allahu

130 Akbar, Bismillah Allahu Akbar (Riaz and Chaudry, 2004).

131

Processing Phase: This often involves two sub-processes - assembling the materials needed and the actual processing of these materials. All ingredients including processing aids and materials used with food contact surfaces as well as the equipment must be halal, sourced legally, safe, and used according to legal requirements. Packaging and labelling must be clear and honest (i.e., no adulteration or mislabelling) (Ballin et al., 2009; Ballin, 2010).

Storage Phase: It is important that products are stored and segregated from haram products to avoid cross-contamination. What is acceptable "segregation" is the responsibility of the halal certifying agency. Food packaging (ranging from primary, secondary and tertiary packaging) play a role in ensuring products are kept sealed to reduce potential contamination.

Logistics: Throughout the food supply chain, the logistics service provider plays a crucial role in ensuring that the raw materials, ingredients, packaging materials, storage and transportation of halal products is done so that they do not become contaminated with haram products.

Audit: The traceability of halal products requires proper tracking of the actual product and certification of its halal status by a local Islamic authority and/or a reputable certification body. The drive for profit should not lead to compromising of the halal integrity. Although audit can only provide a snapshot of compliance with halal requirements, it is not feasible for any authority to monitor the whole chain, hence the need to have faith in the wholesomeness of the product (Alqudsi, 2014). 
153 Figure 1 illustrates the application of halal integrity at the local operational levelwithin a food

154 production (i.e. animal husbandry, aquaculture) or processing._-However, as the halal food trade and 155 personal travel increases, how can the authenticity of the halal status of a food product be assured? 156 
The question of authenticity is paramount to this debate particularly as the halal food trade and travel increases. The global halal food trade is primarily linked with the rise in the global Muslim population and the increase of transnational trade. In 2010, there were 1.6 billion Muslims with a projected growth to 2.2 billion people by 2030 at an average annual growth of $1.8 \%$ (Pew Research Center, 2011). This will make the Muslim population just over one quarter of the world population, representing a 35\% increase since 2010. Australia, Canada, Europe and U.S.A. are emerging with growing Muslim populations and as major markets for halal trade and consumption (Alqudsi, 2014). The rise in population will undoubtedly boost the growth of the halal consumer market and sales. In 2011 , this halal product market was worth a staggering US $\$ 2.3$ trillion of which just over $50 \%$ of the market (US \$1.4 trillion) was for food and beverages (Ahmad et al., 2011). To be part of the market can be potentially beneficial for non-Muslim countries to have Halal certification and labelling (Demirci et al., 2016; Ruzevicius, 2012). This equated in 2012 to just less than $17 \%$ of the global food and beverages market and is projected to rise to US $\$ 1.8$ trillion by 2018 , capturing approximately $20 \%$ of the global market (Arab News, 2016). Further, with the growth of the Muslim population the halat travel industry is projected to grow too. In 2015 the "Muslim travel market was worth US $\$ 145$ billion with 108 million Muslim travellers representing 10\% of the entire travel economy." This halal tourism market is projected to grow to US $\$ 200$ billion by 2020 representing over $13 \%$ of the tourism market and this will further increase the need for halal food and beverages (Halal Tourism, 2015).

With the expected growth of the halal food sector, the issue of global sourcing of raw materials and ingredients will require new efforts to assure halal traceability between countries. This is where traceability, identity preservation techniques, and the integrity of the halal certifying bodies can all contribute. As also noted by the Codex Alimentarius Commission (CAC/GL 24 - 1997), the term halal is subjected to different interpretations by the different schools of thought or jurisprudence particularly Shāf ì , Hanbalī , Mālikì , Hanafî in the Sunni tradition. But they do not differ with respect to haram. The differences between the legal schools of thought revolve around technicalities that must be respected.

It should be noted that there is unanimous agreement regarding what constitutes a most perfect slaughter. This is the requirement for a healthy and alive lawful animal to be slaughtered by a Muslim reciting 'In the name of Allah, Allah is the Greatest' cutting all four tubes or vessels - trachea, esophagus and both external jugular veins, although the question of reversible stunning remains controversial.Beyond the extent of permitted reversible stunning, differences exist about the details of which tubes in the neck need to be cut. Imām Shāfi' is of the view that it is obligatory to cut the trachea and the esophagus whilst the dominant view of Imām Mālik is to cut into the trachea and both external jugular veins. Imām Ahmad b. Hanbal has two views reported. One stipulates all four tubes being cut and the other is in agreement with Imām Shāfi'T. Imām Abu Hanīfā is of the opinion 

that three of the four tubes, irrespective of whichever three, should be cut. To this end, there is also agreement on the cutting point (where the throat meets the upper part of the chest) and the need to

Whilst there are differences regarding secondary details, there is agreement on the need to allow Because of these differences, Kamali (2008) suggested the setting up of an international Shariah advisory forum to develop a leadership role in dealing with this issue and similar issues, and to advise on and resolve areas to minimise differences. These types of international standards may assist in the harmonisation and recognition of halal standards. Whilst it would be helpful to achieve some degree of harmonisation and recognition of halal standards, the practicalities are much more complex and can become politicised to where there is an effort to impose a secular view on the religious communities. An example of such an attempt to tell the religious communities that believe in religious slaughter what to do was an EU funded project. The Religious Slaughter: Improving Knowledge and Expertise through Dialogue and Debate on Issues of Welfare, Legislation and Socio-economic Aspects (DIALREL) (www.dialrel.eu) was carried out to provide a platform to share and address issues relating to religious slaughter between stakeholders and interested parties in 2006-2010 (DIALREL 2010). But, this attempt was not seen as a dialogue rather it was received as a monologue and imposition of secular thought with limited attention given to religious slaughter practices and engagement with religious communities (Regenstein, 2010).

The key to improved halal integrity in international trade is transparency so that consumers can make informed decisions (Alqudsi 2014; Farouk et al. 2016). The certifying agency located and supervising in one country must clearly define the standards used for any particular product, especially with respect to slaughter. It must also assure that the company/slaughter/products comply with the standard it has announced. In many cases agencies will certify products using different standards for different countries and thus the certifying agencies need to also be sure to maintain product integrity and only send a product to a receiver under a different certifying agency that meets that agency's standard (Figure 2). Halal standards are used to make halal production more unambiguous (van der Spiegel et al., 2012). Ideally the role of governments as accreditation bodies is to assure that the companies and the certifying agencies are saying what they do and doing what they say. Having governments staying out of certification but focusing on accreditation means that the Muslim citizens in any one country will have access to products that meet their different standards and the certifying agencies can compete to best serve consumers. In practice this generally means that competing certifying agencies tend to help police each other.

\section{Insert Figure 2 here}


233 There are different interpretations of halal by the different schools of thought and these are modified

234 by the customs of different countries. Figure 2 raises the issue of where a local Islamic authority's

235 halal certificate is not recognised by an agency in a different country. Even with the adoption of a

236 standardised or benchmarked halal standard, countries or certification bodies may still choose to

237 remain independent. A certification body such as JAKIM from Malaysia recognises 54 certification

238 bodies from 32 foreign halal certification bodiescountries and 4 authorities but delisted 4 certification

239 bodies (Halal Malaysia Official Portal 2016). But are those rejections based on alternate

240 interpretations of halal, non-compliance with halal requirements, or a political decision? In addition to

241 cross recognition of halal certification bodies, at times local government bodies do not have the

242 resources to carry out inspections globally and are required to outsource responsibilities to Muslim

243 organisations around the world such as Islamic Food Council of Europe (IFCE) and Islamic Food and

244 Nutrition Council of America (IFANCA) to carry out inspections. This triggers a transnational

245 governmentality on a global scale (Fischer, 2016).

246

247

Thus governments are encouraged to take on the accreditation role to strengthen the whole system,

248 while removing themselves from certification. There are attempts to harmonize halal standards which

249 may benefit the food trade and operational efficiency across countries. Analyses of harmonisation or

250 maintaining independent halal standards will result in different strengths, weaknesses, opportunities

251 and threats. SWOT analyses were divided into two categories in Figure 2 to provide a guideline for

252 countries that opt to select standardised halal standard or choose to have an independent halal

253 standard certification. Countries that opt to use standardised halal standard may benefit from

254 increased cost efficiency and increased food trade. However, there are also threats that there will be

255 reduced variety and freedom of practise according to different schools of thought. Countries that

256 choose to use independent halal standards may benefit from increased competition and the potential

257 to save cost as no benchmarking is required. Meanwhile, although independent halal standards

258 ensure the freedom to adopt halal practices according to their school of thought (and the country's

259 tradition), a reduction in food trade and lack of food choices may prevail.

260 or maintaining indepentent hatalstandats will result in differents strengths, weaknesses,

261 epportunities and threats. Hence, Figure 2 is presented as a strategie global halal supply chain model

262 to provide pragmatic information for countries or certification bodies to better serve Muslims with

263 different traditions. However, the SWOT analyses serve as a guideline as Ab Talib and Abdul Hamid,

264 (2014) reported that SWOT analysis done may be outdated as the environments are constantly

265 changing. In addition to relying on halal standards and certification, laboratory analyses can be used

266 to monitor specific haram ingredients in raw materials and food products such as the presence of

267 porcine and alcohol (van der Spiegel et al., 2012), identification of animal species in food (Aida et al.,

268 2005, 2007) and origin of food product (Ebeler, 2007). According to Fauzi and Mas'ud (2009)

269 scientific justification and results of laboratory analyses can provide additional information for local

270 and regional Islamic authorities to evaluate the halal status of the products. 
One step to better cooperation but while maintaining minor differences related to the schools is the halal standard developed by the Turkish Halal Certification Centre (GIMDES) that incorporates different Schools of Islamic law. A tick $(\sqrt{ })$ image in the logo can be added beside the appropriate schools of law (i.e. Shāf ì, Hanbalī , Mālikī , Hanafi) according to which rules the certified company has complied (Figure 3). The certification can represent one or even all of the schools of law (GIMDES, 2015). But given that Turkey is predominantly a Sunni country, to date this form of certification does not address the Shi'a schools. It also implies that the application of standards by schools is sufficient. In some cases, e.g., whereich fish are considered halal, it is apparent that there are also different customs in different countries that reflect the different schools but lead to differences within each school.

283

Insert Figure 3 here

285

Malaysia recogniszzes the significance of halal assurance of food and consumer products produced globally. It currently accepts products and premises certified by a number of Islamic certification bodies and authorities. Globally, JAKIM recognizes $5 \underline{4}$ foreign halal certification bodies (Halal Malaysia Official Portal, 2016). Additionally, JAKIM recognizes 4 national authorities that will be able to provide guidance for consumers when purchasing halal goods or patronizing certain premises overseas (Halal 
control points for halal slaughtering of poultry (Shahdan et al., 2016) and halal compliance critical control point (Kamaruddin et al. 2012) for various production systems. There are certainly challenges in ensuring halal integrity in the food supply chain as production, processing and transportation require different companies at various stages. Alqudsi (2014) had reported that it is a difficult task to maintain halal integrity of the whole supply chain as it requires constant monitoring and resources in terms of capital and trained staff. However, the demand for halal food products from consumers and the drive from the supply side theory of religion (i.e. expansion of halal markets because of production sides' initiative in creating more halal food) will spur the need to ensure halal food status is maintained. Halal certification bodies play an important role in certifying halal food products and services whilst governments should play an active role as accreditation bodies or to provide

\section{Conclusion}

The ideas of halal and haram are clear within Islamic teachings. It is important also to understand that halal is a way of life and embraces good conduct and righteous deeds. It is in this context that halal integrity should be understood. This paper utilises the farm to fork and global supply chain models to foster a critical awareness of halal needs. Taking into consideration the origins of food products, production and facilities (i.e. operational level), global sourcing of ingredients and raw materials, food trade and halal as a way of life leads to a definition of halal integrity. SWOT analyses serve as a guideline for countries that opt to select standardised halal standard or choose to have an independent halal standard certification. Countries that opt to use standardised halal standard may benefit from increased cost efficiency and increased food trade while countries that choose to use independent halal standards may benefit from increased competition and the potential to save cost as no benchmarking is required. It is recommended that the key to improved halal integrity in international trade is transparency and required concerted effort from food supply chains, policy makers, halal certification \& accreditation bodies and research institutions. Halal integrity is crucial to the success of halal market - if the halal status of the food product is breached (e.g. did not follow halal slaughtering method, cross contamination with haram products, ill intentions), this will render the product haram. In response to the initial questions raised in this paper, i.e., what is halal integrity and what measures can be taken to assure this - a formal definition of halal integrity has 
been proposed._ Halal integrity is need both operationally and strategically to ensure that the halat

349

\section{References}

Ab Talib, M. S. and Abdul Hamid, A. B. (2014), "Halal logistics in Malaysia: a SWOT analysis", Journal of Islamic Marketing, Vol. 5, No. 3, pp. 322-343.

Adam, M. (2016), "The figh of halal and haram animals", available at http://www.centralmosque.com/index.php/General-Fiqh/the-fiqh-of-halal-and-haram-animals.html (accessed 12 March 2016).

Ahmad, H., Fazlullah, A., Borham, A.J., Hashim, H. and Razak, M.A. (2011), "Halal studies in universities: A way forward to manage halal business", International Journal of Arts and Science Conference (IJAS2011) 3 June, Austria.

Aida, A. A., Che Man, Y. B., Raha, A. R. and Son, R. (2007), "Detection of pig derivatives in food products for halal authentication by polymerase chain reaction-restriction fragment length polymorphism", Journal of the Science of Food and Agriculture, Vol. 87, No. 4, pp. 569-572.

Aida, A. A., Che Man, Y. B., Wong, C. M. V. L., Raha, A. R. and Son, R. (2005), "Analysis of raw meats and fats of pigs using polymerase chain reaction for Halal authentication", Meat Science, Vol. 69 , No. 1 , pp. 47-52.

Al-Bukhārī, M. (trans. Muhammad Muḥsin Khān) (n.d.), The Translation of Meanings of Al-Sahịh alBukhārī, (vol. 1-9), Dār al-Fikr, Beirut, Lebanon.

Al-Mawsu'a al-figh al-Kuwaitiyyah (n.d.). vols. 1-45. Wizaratul al-awqaaf wa al-sh'uwn al-Islamiyyah $1404 / 1984-1427 / 2006$

Al-Qardawi, Y. (2013) (trans.). El-Helbawy et al. The Lawful and The Prohibited in Islam, Kualal Lumpur: Islamic Book Trust

Al-Qazwini, M. (n.d.) Sunan Ibn Mājah, Kitāb al-Ațimah, Chapter 31, Hadith 3314, (vols. 1-2), p. 1102, Dār al-'Ilmīyyah, Beirut, Lebanon.

Alqudsi, S. G. (2014), "Awareness and demand for $100 \%$ halal supply chain meat products", Procedia - Social and Behavioral Sciences, Vol. 130, pp. 167-178.

Al-Zuhayli, W. (2002) (vol. 4) Al-Fiqh al-Islam wa Adilatuhu, Syria: Damascus: Dar al-Fikr, pp. 27902792]

Arab News (2016), "Halal food market grows to $\$ 1.1$ trillion industry", available at http://www.arabnews.com/news/economy/614871 (accessed 12 March 2016).

Ballin, N. Z. (2010), "Authentication of meat and meat products", Meat Science, Vol. 86, No. 3, pp. 577-587.

Ballin, N. Z., Vogensen, F. K. and Karlsson, A. H. (2009), "Species determination - Can we detect and quantify meat adulteration?" Meat Science, Vol. 83, No. 2, pp. 165-174.

BBC News (2013), "Leicester schools halal lamb burger contained pork", 9 May, available at: http://www.bbc.com/news/uk-england-leicestershire-22466068 (accessed 3 April 2015).

BBC News (2013), "Leicestershire schools' flu vaccine contains gelatine", 17 September, available at http://www.bbc.com/news/uk-england-leicestershire-24113970 (accessed 3 April 2015). 
Bergeaud-Blackler, F. (2007), "New challenges for Islamic ritual slaughter: A European perspective", Journal of Ethnic and Migration Studies, Vol. 33 No. 6, pp. 965-980.

Bottaro, M., Marchetti, P., Mottola, A., Shehu, F. and Pinto, A. (2014), "Detection of mislabeling in packaged chicken sausages by PCR", Albanian Journal of Agricultural Sciences, Special Edition (2014), pp. 455-460.

CAC, Codex Alimentarius Comission (1997), CAC/GL 24-1997 General guidelines for use of the term "Halal", Codex Alimentarius Comission.

Cawthorn, D.-M., Steinman, H. A. and Hoffman, L. C. (2013), "A high incidence of species substitution and mislabelling detected in meat products sold in South Africa", Food Control, Vol. 32, No. 2, pp. 440-449.

Chandia, M. (2015), Translation of the Holy Qur'an, Azhar Academy, London.

Demirci, M. N., Soon, J. M. and Wallace, C. A. (2016), "Positioning food safety in halal assurance", Food Control, Vol. 70, pp. 257-270.

Demirhan, Y., Ulca, P. and Senyuva, H. Z. (2012), "Detection of porcine DNA in gelatine and gelatinecontaining processed food products - Halal/Kosher authentication," Meat Science, Vol. 90, No. 3, pp. 686-689.

DIALREL (2010), "Encouraging dialogue on issues of religious slaughter", available at: http://www.dialrel.eu/ (accessed 24 January 2016).

Doosti, A., Ghasemi Dehkordi, P. and Rahimi, E. (2011), "Molecular assay to fraud identification of meat products", Journal of Food Science and Technology, Vol. 51 No. 1, pp. 148-152.

Di Pinto, A., Bottaro, M., Bonerba, E., Bozzo, G., Ceci, E., Marchetti, P., Mottola, A. and Tantillo, G. (2015), "Occurrence of mislabelling in meat products using DNA-based assay", Journal of Food Science and Technology, Vol. 52, No. 4, pp. 2479-2484.

Di Pinto, A., Forte, V. T., Conversano, M. C. and Tantillo, G. M. (2005), "Duplex polymerase chain reaction for detection of pork meat in horse meat fresh sausages from Italian retail sources", Food Control, Vol. 16, No. 5, pp. 391-394.

Ebeler, S. E. (2007), "Enantiometic analysis as a tool for authentication of foods and beverages", In, Ebeler, S. E., G. R. Takeoka and P. Winterhalter (Eds.). Authentication of food and wine, Vol. 952, pp. 39-49.

Eliasi, J. R. and Dwyer, J. T. (2002), "Kosher and halal: Religious observances affecting dietary intakes", Journal of the American Dietetic Association, Vol. 102 No. 7, pp. 911-913.

EU (1993), "Council directive 93/119/EC of 22 December 1993 on the protection of animals at the time of slaughter or killing", Available at: http://ec.europa.eu/food/fs/aw/aw_legislation/slaughter/93119-ec_en.pdf [Accessed 7 June 2016]

Farouk, M. M., Pufpaff, K. M. and Amir, M. (2016), "Industrial halal meat production and animal welfare: A review", Meat Science, doi: doi:10.1016/i.meatsci.2016.04.023

Fauzi, A. M. and Mas'ud, Z. A. (2009), "Instrumentation techniques for potential application in halal products authentication. $3^{\text {rd }}$ IMT-GT International Symposium on Halal Science and Management, 2122 December 2009, Kuala Lumpur, Malaysia. 
Fischer, J. (2016), "Markets, religion, regulation: Kosher, halal and Hindu vegetarianism in global

Flores-Munguia, M. E., Bermudez-Almada, M. C. and Vazquez-Moreno, L. (2000), "A research note: Detection of adulteration in processed traditional meat products", Journal of Muscle Foods, Vol. 11, No. 4, pp. 319-325.

GIMDES (2015), "GIMDES certification standards", available at:

http://www.halalcertificationturkey.com/en/certification-information/certification-standarts/_accessed 15 January 2016).

Halal Malaysia Official Portal (2016), "The recognised foreign halal certification bodies and authorities", available at: http://www.halal.gov.my/v4/index.php/en/badan-islam/badan-luar-negaradiiktiraf (accessed 13 January 2016).

Halal Tourism (2015), "150 million visitors worth $\$ 200$ billion: The story has just begun", available at: http://www.guesthousesofmaldives.com/halal-tourism-150-million-visitors-worth-200-billion-the-storyhas-just-begun/ (accessed 29 February 2016).

Hoorfar, J., Jordan, K., Butler, F. and Prugger, R. (2011), "Food chain integrity: A holistic approach to food traceability, safety, quality and authenticity", Cambridge: Woodhead Publishing, pp. 1-338.

Ibn Al-Ḥajjāj, M. (1987). Saḥịh Muslim bi Sharh al-Nawawī, Kitāb al-Musāqah, part 11, vol. 4 (first ed.), p. 27, Dar al-Rayyān, Cairo, Egypt.

Kamali, M. H. (2008), "Figh-based approach to harmonisation of halal standards", The Halal Journal (May \& June), available at: http://issuu.com/the-halaljournal/docs/mayjune2008_20100721_093430/25 (accessed 15 January 2016).

Kamaruddin, R., Iberahim, H. and Shabudin, A. (2012), "Halal compliance critical control point (HCCCP) analysis of processed food", IEEE Business, Engineering \& Industrial Applications Colloquium (BEIAC), pp. 383-387.

Kohilavani, Yang, T. A., Febrianto, N. A., Abdullah, W. and Tajul Aris, A. (2012), "A decision tree based approach for the identification of Halal Critical Control Points for slaughtering according to Islamic dietary law", Internet Journal of Food Safety, Vol. 14, 48-53.

Kohilavani, Zzaman, W., Febrianto, N., Zakariya, N., Abdullah, W. and Yang, T. (2013), "Embedding Islamic dietary requirements into HACCP approach", Food Control, Vol. 34 No. 2, 607-612.

Lever, J. and Miele, M. (2012), "The growth of halal meat markets in Europe: An exploration of the supply side theory of religion", Journal of Rural Studies, Vol. 28, pp. 528-537.

Lipes, J. (2013), "Foods mislabeled as halal imports", 18 January, Radio Free Asia, available at: http://www.rfa.org/english/news/uyghur/halal-01182013161229.html (accessed 3 April 2015).

Manning, L and Soon, J.M. (2014), "Developing systems to control food adulteration", Food Policy, Vol. 49 No. 1, pp. 23-32.

Muñoz-Colmenero, M., Martinez, J., Roca, A. and Garcia-Vazquez, E. (2016), "Detection of different DNA animal species in commercial candy products", Journal of Food Science, Vol. 81, No. 3, pp. T801-T809.

Muslim Food Board (2016), "Importance of halal diet", available at:

http://www.tmfb.net/component/tags/tag/30-doubtful (accessed 26 March 2016). 
Pew Research Center (2011), "The future of the global Muslim population: Projections for 20102030", available at http://www.pewforum.org/files/2011/01/FutureGlobalMuslimPopulation-WebPDFFeb10.pdf (accessed 12 March 2016).

Press Association (2015), "Abattoir clips highly regrettable", 3 February, Daily Mail, available at: http://www.dailymail.co.uk/wires/pa/article-2937224/Halal-slaughterhouse-video-probed.html (accessed 13 April 2015).

RASFF, Rapid Alert System for Food and Feed (2013), "RASFF portal", available at:

https://webgate.ec.europa.eu/rasff-window/portal/?event=SearchForm\&cleanSearch=1 (accessed 16 January 2016).

Riaz, M. N., and Chaudry, M. M. (2004). Halal food production. CRC Press, LCC., Boca Raton, FL, USA.

Regenstein, J. M. (2010), "DIALREL recommendations: comments of Prof. Regenstein", available at: http://www.asidcom.org/DIALREL-recommendations-comments.html (accessed 15 March 2016).

Ruzevicus, J. (2012), "Products quality religious-ethical requirements and certification. Economics and Management, Vol. 17, No. 2, pp. 761-767.

SGS (2011), "Comparing Global Food Safety Initiative (GFSI) recognised standards", available at: http://www.sgs.com/ /media/Global/Documents/White\%20Papers/sgs-global-food-safety-initiativewhitepaper-en-11.ashx (accessed 15 January 2016).

Shahdan, I. A., Regenstein, J. M., Shahabuddin, A. S. M. and Rahman, M. T. (2016). "Developing control points for halal slaughtering of poultry", Poultry Science doi: 10.3382/ps/pew092

Soares, S., Amaral, J. S., Oliveira, M. B. and Mafra, I. (2013), "A SYBR green real-time PCR assay to detect and quantify pork meat in processed poultry meat products", Meat Science, Vol. 94, No. 1, pp. 115-120.

Soon, J. M. and Baines, R. (2013). Managing food safety risks in the agri-food industries. Boca Raton: CRC Press.

Soon, J. M., Manning, L., Davies, W. P. and Baines, R. (2012). "Fresh produce-associated outbreaks: a call for HACCP on farms?" British Food Journal, Vol. 114, No. 4, pp. 553-597.

Trenwith, C. (2013), "Fast food giant to pay $\$ 700 \mathrm{k}$ for halal mislabelling", Arabian business, available at: http://m.arabianbusiness.com/fast-food-giant-pay-700k-for-halal-mislabelling-498543.html (accessed 3 April 2015).

Uthmani Mufti, T.M. (2005), "Legal rulings on slaughtered animals", trans. Nana, A., p. 13, available at http://freepdfhosting.com/d3a6d6755e.pdf (accessed 27 February 2016).

Van der Spiegel, M., van der Fels-Klerx, H. J., Sterrenburg, P., van Ruth, S. M., Scholtens-Toma, I. M. J. and Kok, E. J. (2012), "Halal assurance in food supply chains: Verification of halal certificates using audits and laboratory analysis", Trends in Food Science \& Technology, Vol. 27, No. 2, pp. 109-119.

Whitworth, J. (2013), "FSA calls urgent meeting after pork DNA found in halal meat", 4 February, Food Production Daily, available at http://www.foodproductiondaily.com/Safety-Regulation/FSA-callsurgent-meeting-after-pork-DNA-found-in-halal-meat (accessed 25 March 2015).

Zulfakar, M. H., Jie, F. and Chan, C. (2012), "Halal food supply chain integrity: From a literature review to a conceptual framework", $10^{\text {th }}$ ANZAM Operations, Supply Chain and Services Management Symposium, Melbourne, Australia, 14-15 ${ }^{\text {th }}$ June 2012. 
1

2

3

4

5

6

7

8

9

10

11

12

13

14

15

16

17

18

19

20

21

22

23

24

25

26

27

28

29

30

31

32

33

34

35

36

37

38

39

40

41

42

43

44

45

46

47

48

49

50

51

52

53

54

55

56

57

58

59

60
571 Zulfakar, M.H., Mohamed Anuar, M. and Ab. Talib, M.S. (2014), "Conceptual framework on halal food 572 supply chain integrity enhancement", Procedia - Social and Behavioural Sciences Vol. 121, pp. 58-67. 


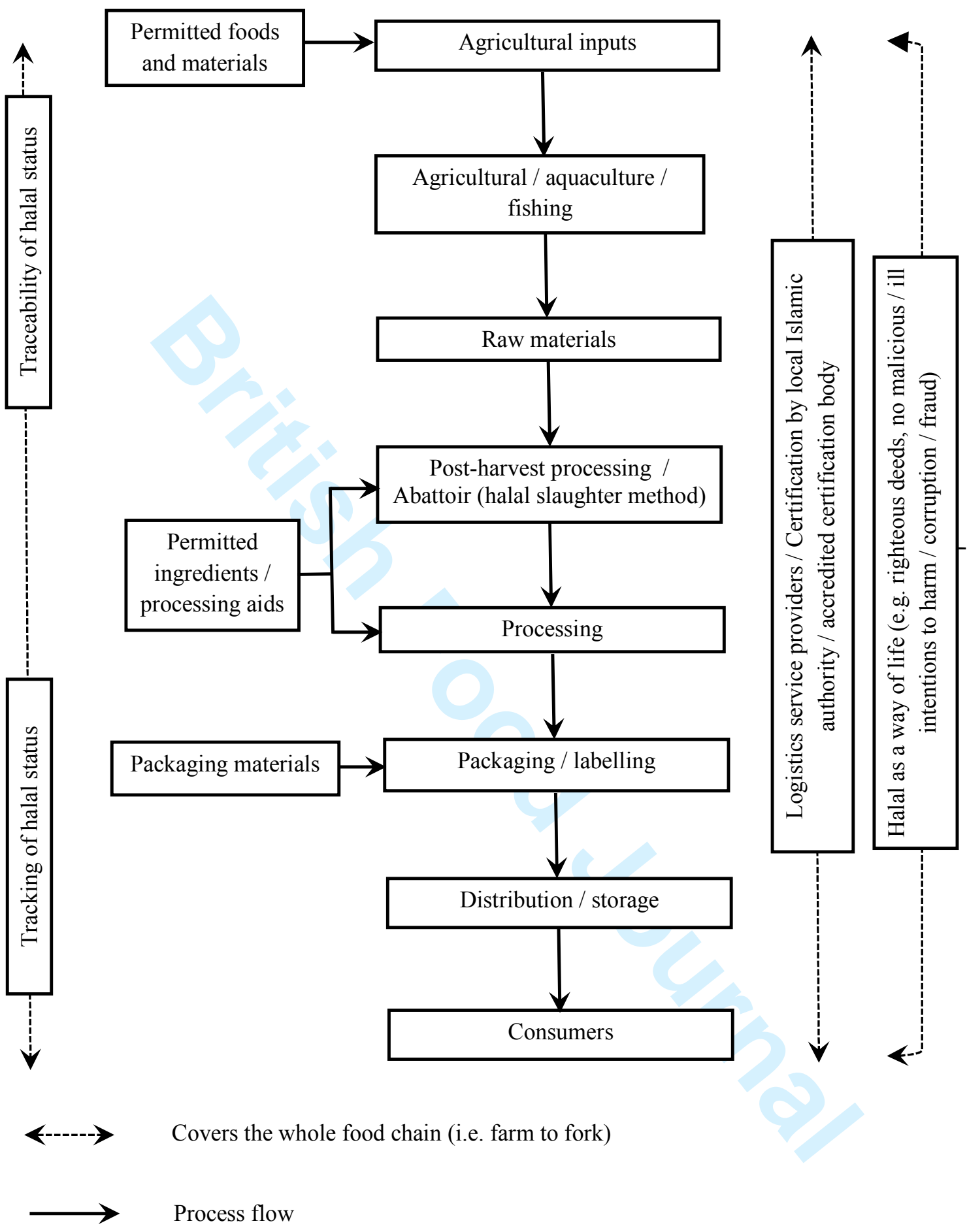

Figure 1. Halal integrity from farm to fork 
Strengths, weaknesses, opportunities and threats (SWOTs) analysis of a global standardised / benchmarked halal standard

\begin{tabular}{|c|c|}
\hline $\begin{array}{l}\text { Strengths } \\
\text { - Cost efficiency in the } \\
\text { long run } \\
\text { - Operational efficiency } \\
\text { - Import / export } \\
\text { capability } \\
\text { - Increased global } \\
\text { training and capacity } \\
\text { building }\end{array}$ & $\begin{array}{l}\text { Opportunities } \\
\text { - Harmonised halal } \\
\text { standard } \\
\text { - Potential for equivalence } \\
\text { and convergence (SGS } \\
\text { 2011) } \\
\text { - Increased food trade and } \\
\text { varieties for consumers } \\
\text { - Development of } \\
\text { international Shariah } \\
\text { advisory forum } \\
\text { - Halal integrity easily } \\
\text { assured } \\
\end{array}$ \\
\hline $\begin{array}{l}\text { Weaknesses } \\
\text { - Increased cost during } \\
\text { initial set up (e.g. for } \\
\text { benchmarking, } \\
\text { training and capacity } \\
\text { building) } \\
\text { - Convergence only to a } \\
\text { certain point due to } \\
\text { different school of } \\
\text { thoughts }\end{array}$ & $\begin{array}{l}\text { Threats } \\
\text { - Local Islamic authorities } \\
\text { / halal standard owners } \\
\text { may feel threatened } \\
\text { - Monopoly by one halal } \\
\text { standard } \\
\text { - Reduced variety and } \\
\text { freedom to practise } \\
\text { according to different } \\
\text { schools of thought }\end{array}$ \\
\hline
\end{tabular}

- Conduct trade with other countries with appropriate halal products

- Inspections by Islamic authorities, $2^{\text {nd }}$ or $3^{\text {rd }}$ party audit (e.g. own company / appoint recognised certification body to conduct halal audit trail in country $\mathrm{A} / \mathrm{B}$

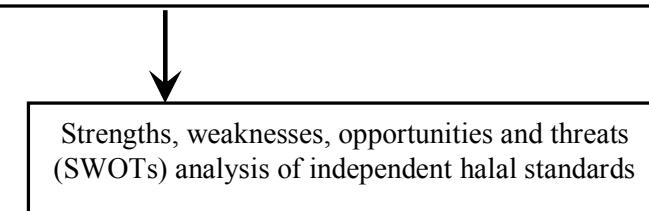

\begin{tabular}{|c|c|}
\hline $\begin{array}{l}\text { - Strengths } \\
\text { - Save cost for existing } \\
\text { halal standard owners } \\
\text { (no benchmarking / } \\
\text { review of standards } \\
\text { required) } \\
\text { - Provision of local } \\
\text { training and capacity } \\
\text { building } \\
\text { - Freedom to adopt halal } \\
\text { practices according to } \\
\text { different schools of } \\
\text { thought }\end{array}$ & $\begin{array}{l}\text { Opportunities } \\
\text { - Increased competition } \\
\text { between halal standard } \\
\text { owners } \\
\text { - Reduction of monopoly by } \\
\text { one standard owner } \\
\text { - Increase local } \\
\text { entrepreneurial activities to } \\
\text { meet demand for local } \\
\text { products } \\
\text { - Reduce dependency on } \\
\text { import products }\end{array}$ \\
\hline $\begin{array}{l}\quad \text { Weaknesses } \\
\text { - Difficult to audit } \\
\text { - Requires } 2^{\text {nd }} \text { or } 3^{\text {rd }} \text { party } \\
\text { audit (increased costs) } \\
\text { to ensure halal integrity } \\
\text { in other regions }\end{array}$ & \begin{tabular}{l}
\multicolumn{1}{c}{ Threats } \\
- Reduction in food trade \\
- Reduction in food choices \\
for consumers \\
- Reduction in food trade - \\
can we still cope with \\
increasing demand for \\
halal products? \\
- Continuous debates and \\
emergence of different \\
interpretations of Islamic \\
dietary laws
\end{tabular} \\
\hline
\end{tabular}

Figure 2. Assuring global halal integrity via recognised halal certification bodies 
British Food Journal

Page 18 of 20

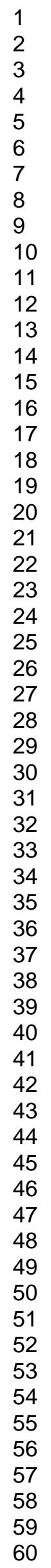


Table 1. Examples of food cross-contamination with porcine products and mislabeling cases 
2014 Turkey Gelatine products $\quad \underline{\text { Products contain porcine (Demirhan et al., 2012) }}$

(marshmallow and gelatine and labelling

gum drops)

failed to indicate the use

of pork gelatine

2015 UK Halal slaughter Not following halal

practices in the

(Press Association, 3

house

slaughtering process

$\underline{2015} \underline{\text { Italy }}$ Chicken sausages

Detection of pork DNA in chicken sausages

2016 Spain $\underline{\text { Marshmallows, }}$

Detection of poreine

Muñoz-Colmenero et

gummies, hard

DNA in commercial

February 2015)

candies and candy products

Di Pinto et al., 2015

\section{complex candies}

